\title{
The effect of perceived value by the tourists toward electronic word of mouth activity: the moderating role of conspicuous tendency
}

\author{
Sukaris Sukaris ${ }^{1,2 *}$, Sri Hartini ${ }^{2}$ and Dien Mardhiyah ${ }^{2}$ \\ ${ }^{1}$ Faculty of Economics and Business, Universitas Muhammadiyah Gresik, East Java, Indonesia. \\ ${ }^{2}$ Faculty of Economics and Business, Universitas Airlangga, Surabaya, Indonesia. \\ *Corresponding author: sukaris-2016@feb.unair.ac.id
}

\begin{abstract}
Managers of tourist destinations are currently trying to offer attractions and attractive destination resources to be visited by tourists. However, very few managers of tourist destinations, especially adventure tourism who pay attention to the values that will be obtained by tourists and also very little attention to the tendency behavior of consumers to show off when visiting tourist attractions, in which they will then recommend their activities to others through digital media. The purpose of this study is to analyze the effects of the perceived values by tourists, consisting of emotional value and epistemic value towards the activity of electronic word of mouth of tourists moderated by conspicuous tendencies. The population in this study is visitors who carry out adventurous activities in adventure tourism destinations, with a sample of 400 tourist. Hypotheses are tested by using structural equation modeling. The results of the study provide information that the emotional value affects the activity of electronic word of mouth of tourists. Likewise, the novelty value influences the activity of electronic word of mouth of tourists, while the conspicuous tendencies variable of tourists weakens the effect of emotional value on the activity of electronic word of mouth of tourists. Finally, the conspicuous tendencies variable of tourists can be a variable which strengthens the effect of epistemic value on the activity of electronic word of mouth of tourists.
\end{abstract}

Keywords: The perceived value, emotional, epistemic, electronic word of mouth, conspicuous tendencies \begin{tabular}{ll}
\hline JEL Classification Code: M31, M37 DOI: 10.20885/jsb.vol24.iss1.art1 & D.
\end{tabular} Introduction

Nowadays, there has been a shift in the consumption patterns of the people. People spend more their money on leisure, experience, entertainment and tourism. This shift is marked by changing consumption patterns in four areas including; decreased household spending on food and clothing, increased spending on durable consumer goods, increased spending on services, and increased spending on leisure (https://faisalbasri.com).

In the tourism business, the shift in consumption patterns for managers of tourist destinations enables the management and marketing of tourist destinations to be an important thing. In general, marketing tourist destinations means designing tourist attractions to be able to meet the desires and expectations of tourists. For this reason, it is necessary to create a management pattern which emphasizes the competitive advantage of the tourist sites and is not just different. This rationale then underpins how tourist destinations should be able to have superior differences that can provide the best experience for tourists. Based on that, the managers of the tourist destination will get a double benefit, they are economically getting an increase in tourists and positive activities of tourists after the tour, which is telling the destination to other parties both directly and through internet-based media (EWOM) for the experience they have gained during the visiting activities in tourist destinations.

Tourists are often involved in electronic word of mouth (EWOM) or interpersonal communication activities as a means of sharing the best experiences to express the excitement gained during a tour. EWOM activities are seen as part of the activities after the purchase process. In marketing research and consumer behavior, EWOM is seen as a tourist activity after visiting tourist destinations (Albaity \& Melhem, 2017; Sangpikul, 2017; Chen \& Rahman, 2018; Ekinci et al., 2013; Han et al., 2016; Liu et al., 2012; Lu \& Xu, 2015; Serra et al., 2018). 
The effect of perceived value by the tourists toward electronic word of mouth activity: the moderating role of conspicuous tendency

EWOM activity in the context of a tourist destination can be compared to a product, in which it can be influenced by factors originating from internal consumers. These factors originating from internal consumers include Self-Congruity, Functional Image, and Emotional Attachment, Personality, Regulatory focus, Motivation, Involvement, Value/beliefs, Lifestyle, Past experience, Self efficacy, Self identity, Pleasure and arousal (Varshneya, et al., 2017). Thus EWOM activities can also be influenced by the values perceived by tourists and can be strengthened by the presence of conspicuous tendencies (visitors' tendency to show off). The dimension of value perceived by tourists during a visit can be emotional or epistemic (Antón et al., 2017; Bora et al., 2018; Halim \& Mokhtar, 2016; Kim et al., 2018; Lee, 2016; Lin \& Kuo, 2016; Mukerjee, 2018; Oh, 1999; Ranaweera \& Karjaluoto, 2017; Varshneya et al., 2017). Previous studies have also examined the interrelations between conspicuous tendencies that can strengthen the influence of experiential value on EWOM such as Kim et al., (2015); House et al., (2015); Kim \& Jang (2017).

Previous studies related to a value of experience in tourist destinations have been conducted by Ekinci et al., (2013); Chen et al, (2016); Esmaeilpour, (2015); Gazley \& Watling, (2015); Gbadamosi, (2015); Wymer \& Samu, (2002); Kwak \& Kang, (2009); Larsen et al., (2010); Sun et al., (2014); Williams \& Soutar, (2009) but these studies have not yet included a need which is currently being carried out such as showing off, or the need to be seen by others.

In the perspective of the tourism industry, tourist experience will be able to influence EWOM activity of tourists. Many studies have been done on EWOM that is influenced by the value of experience, such as Prebensen \& Rosengren (2016); Prebensen et al., (2014); Williams \& Soutar, (2009), the perceived experience value can be in the form of functional, conditional, social, emotional, and epistemic values. The value of experience includes interactions which give relative preference to the individuals involved. Therefore, the perception of the value of experience, especially regarding holidays, involves tourists who participate in the creation of a value. The study of Williams et al., (2017) states that emotional value and epistemic value become strong predictors of tourist satisfaction, hence in this study emotional value and epistemic value become an important part of measuring the value of experiences gained by tourists.

The value of experience gained in conducting tourist activities can be in the form of emotional value and epistemic value. Emotional value will be able to affect EWOM only if when the tourists visit tourist destinations, they get a sense of pride, get a sense of comfort, get a sense of happiness, and get a sense of confidence. Likewise with the epistemic value obtained by tourists, it will affect EWOM only if when the tourists visit tourist destinations, they get the real experience, can satisfy curiosity, feel like a tourist destination character, get a unique experience and get a new experience. Thus tourists' EWOM activities will increase if the tourists visiting tourist destinations find themselves having a pleasant, happy experience and getting something new. It will be different if tourists are disappointed when visiting tourist destinations, so tourists are reluctant to share positive information with others.

Another factor in the destination context that can strengthen or weaken EWOM activities is the tendency of tourists to show off after a visit. In this study the tendency to show off takes the term conspicuous consumption (excessive consumption, striking, showing self and showing off). Research related to the need to show off in the field of marketing and consumer behavior has been carried out in the last 5 years, such as Bajac et al., (2018); Bronner \& de Hoog (2018); Dev et al., (2018); Amatulli et al., (2018); O'Cass (2018); Nabi et al., (2019); Shao et al., (2019) but research that connects the needs of showing off with WOM has not been done much (Kim et al., 2015; House et al., 2015; Kim \& Jang, 2017). Other studies such as Chaudhuri et al., (2011); Wang \& Liu, (2007) treat conspicuous consumption as a moderating variable, which links the perceived value with EWOM activity.

At first conspicuous consumption refers to the behavior of consumers who buy expensive goods to show wealth and social status, not to meet actual needs. Kim \& Jang, (2017) provides empirical evidence that the basic motivation of $Y$ generation consumers' premium coffee consumption in Korea is on luxury value dimensions such as materialism, suitability, tendency to show off and 
functional dimensions. Thus the tendency of showing off of tourists will be able to strengthen the perceived value relationship with EWOM activities if tourists want to be valued more by others, want to feel more important, increase popularity, want to be respected by others, show success in life, show unique experiences, show trends and tourists want to show themselves as an adventurer. This notion is reinforced by the assumption that tourists' EWOM activities which originate from feelings of happiness, happiness will be stronger if tourists who have visited can show their tourist experiences to others, recognized their social status by others and the experience gained is valued by others. These conditions may be difficult for tourists if access to share experiences is not supported by internet-based technology.

That not all tourist destinations are able to provide value for tourists and also make tourists need to show through electronic media, only tourist destinations which provide emotional and epistemic values that will make tourists need to show off. Adventure tourism destinations in Indonesia have a different character, so that they can provide a higher value. Special interest in adventure tourism has several advantages including first; the trend of adventure tourists in 2018 has led companies operating in this sector to record a net profit increase of 75 percent, in Indonesia adventure tourism destinations contribute $67 \%$ of tourist expenditure (Adventure Travel Trade Association), although it is still smaller $(20 \%)$ compared to other natural tourist destination products. Second: that the decision to choose a tourist destination can be influenced by motivation originating from internal and external tourists, as the research conducted by Giddy \& Webb (2016); Giddy, (2018); Jamal et al., (2019); Giddy \& Webb, (2018); Pomfret \& Bramwell, (2016); Xu \& Chan, (2016). Therefore, the purpose of this study is to knowing the effect of emotional value and epistemic value on EWOM activities which are moderated by the tendency of tourists to conspicuous tendency.

\section{Literature Review}

\section{E-WOM}

Taking the concept of WOM, EWOM is a digitalization of WOM. The definition of EWOM is all informal communication directed at consumers through internet-based technology related to the use of certain goods and services or the seller. Although taking the concept from WOM, EWOM has differences with WOM in terms of the speed of information dissemination, the relationship between source and receiver of messages and the availability of information. First, EWOM messages quickly spread and have the potential to reach a very broad audience, while messages through WOM are relatively brief and only limited to known people. Second, EWOM recipients are actively involved in seeking a wider variety of opinions online, while WOM depends on the opinions of people who are only known. Third, access to EWOM can be immediate or delayed because online message traces can last permanently and information is now available to anyone who is connected to the internet, while WOM messages are more limited and have short duration of time (Litvin et al., 2008).

Several studies on EWOM have been conducted by Litvin, (2007); Litvin et al., (2008); Hennig \& Thurau, (2010); Chu \& Kim, (2011); Ye \& Yushe, (2009); Goyette, et al., (2010); See et al., (2014) which generally discuss about a product from the company, so that minimal EWOM research is found in the scope of tourism. Consumers usually receive and respond to EWOM messages as a reliable source of interesting and useful information (Bickart \& Schindler, 2001; Gruen, 2006). Litvin et al., (2008:462) revealed that EWOM will change the structure of travel information and then change tourists' knowledge and perceptions of various tourism products.

Tourist behavior has shown evidence of utilizing internet technology to obtain tourist information, share stories and opinions about travel experiences to various social networking sites. This is shown by a study conducted by Xiang \& Gretzel (2010) which states that tourism marketing currently focuses on the use of social media to create a positive image and WOM for tourist destinations and business people. This is strenghtened by Parra-Lopez et al., (2011) who revealed that it was common that electronic media provide benefits as a forum for sharing photos, videos to per- 
The effect of perceived value by the tourists toward electronic word of mouth activity: the moderating role of conspicuous tendency

sonal blogs, rating, evaluating, viewing maps online and so on to share and recommend to fellow users.

Chu \& Kim (2011) stated that the EWOM dimensions which exist in the scope of Social Networking Sites (SNSs) are tie strength, homophily, trust, normative influence, and informational influence. Tie strength is a potential bond which exists among members in a network. Homophily is the degree of similarity of a person in certain conditions, for example the similarity of the mind in receiving messages. Trust is the user's confidence in the information received, also means relying on something to exchange ideas. Normative influence is a tendency to expect others to behave in the same way we feel, in which it is easily influenced by social opinion and approval. Whereas Informational influence is the tendency to receive information conveyed in the search for goods and services.

EWOM presents a new form of communication between the receiver and sender. As described by Cheung \& Thadani (2010), new forms of communication models include the presence of stimulus, communicator, receiver, and response. Stimulus is a message sent containing positive, negative or neutral messages. Usually this stimulus is in the form of consistency and the number of reviews from other authors. Communicator means someone who conveys a message, usually involving expertise, interests and similarity. The message conveyed through e-WOM is not always personal, so that its contents can be enjoyed by anyone. Receiver means a person who responds to e-WOM communication. Responses occured differ from one recipient to another since it involves curiosity, trust, focus of search, social ties and similarity. Response means the response or reaction resulted from communication between the sender and receiver. Factors related to recipient behavior are information adaptation, trust, purchases, loyalty, and social presence (Dellarocas et al., 2007; Watts \& Zhand, 2008; Cheung et al., 2009). While from the point of view of the communication process, Cheung et al., (2009) states that the message conveyed does not only come from the sender but can also come from the recipient at one time so that the EWOM communication process runs interactively resulting in different responses.

\section{The Perceived Value by the Tourists}

The perceived values of tourists for tourist destinations aim to reinforce the benefits which can be obtained by visitors for the costs incurred compared to the benefits to be obtained from the selection of other tourist destinations. Therefore, it can provide a strong encouragement for travel decisions such as repurchases, recommendations to other people, and positive WOM. Positive WOM itself can be linked to the experience that has been felt by tourists and plays an important role in reducing risk for tourists, and has been considered important for business in lieu of advertising without cost.

Zeithaml, (1988) conducted an exploratory study related to the definition of perceived value, in the study he grouped the definition of a value in; 1) Value is a low price, 2) value is whatever is desired in a product, (3) value is the quality obtained for the price paid and (4) value is what is obtained from the sacrifice made. The value perceived by some researchers is measured by several dimensions, for example Williams et al., (2017) functional value, price value for money, emotional value, social value, and novelty value; Yang et al., (2016) identified five measures of value, namely quality value, emotional value, social value, price value, and experiential value; Prebensen \& Rosengren, (2016) used five measurements namely functional value, value for money, emotional value, social value and novelty (epistemic) value.

Emotional value is a benefit derived from feelings or affections (i.e pleasure) produced by a product (Sweeney \& Soutar, 2001). Whereas epistemic value is stated by Ella (2016) as an aspect of surprise or uniqueness and novelty of a product and the capacity of a product to arouse curiosity, provide uniqueness and novelty or satisfy the desire for knowledge. Therefore, the values of experience gained in carrying out special interest tourism activities, can be in the form of emotional value and epistemic value.

The values of experience gained in conducting special interest tourism activities, can be in 
the form of emotional value and epistemic value. Emotional value will be able to affect EWOM only if when the tourists visit tourist destinations, they get a sense of pride, get a sense of comfort, get a sense of happiness, and get a sense of confidence. Likewise with the epistemic value obtained by tourists, it will affect EWOM only if when the tourists visit tourist destinations, they get the real experience, can satisfy curiosity, feel like a tourist destination character, get a unique experience and get a new experience. Thus tourists' EWOM activities will increase if the tourists visiting tourist destinations find themselves having a pleasant, happy experience and getting something new. It will be different if tourists are disappointed when visiting tourist destinations, so tourists are reluctant to share positive information.

In terms of the values of the experience perceived by tourists can be in the form of unidimensional and multi-dimensional, in the context of this study the perceived values often refer to the emotional value and also the epistemic value. Therefore, if tourists feel proud, comfortable, happy and feel confident, it means that tourists have perceived emotional value and will eventually have an effect on WOM activities (Williams et al., 2017). Meanwhile, the epistemic value can have an effect on tourists' WOM activity if the tourists; get real experiences, satisfy their curiosity, feel part of the brand of tourist destination, get unique experiences, and get new experiences (Williams et al., 2017; Prebensen \& Xie, 2017). Other previous studies which support the premise of the effect of perceived values of tourists on tourists' e-WOM activities are; Bora et al., (2018), Mukerjee (2018), Kim et al. (2018), and Ranaweera \& Karjaluoto (2017). On the other hand, the research of Antón et al., (2017) produced different results, in which the epistemic value has no effect on EWOM. Thus the hypotheses proposed are as follows:

H1: Emotional value has positive effect on EWOM tourist activity.

$\mathrm{H} 2$ : Epistemic value has a positive effect on EWOM tourist activity.

\section{Conspicuous Tendencies}

Chaudhuri et al., (2011) states that conspicuous consumption is a deliberate act in symbolic purchases with motivation to communicate a distinctive self-image to others. Jensen \& Gilly, (2003) stated that conspicuous tendencies as a form of excessive self-presentation of the consumption of tourist destinations through social networking sites or blogs. Whereas the e-WOM variable is defined as informal communication directed at consumers through internet-based technology related to the use or characteristics of certain goods and services, or the seller (Litvin et al., 2008).

That e-WOM behavior of tourists which can be influenced by the tendency to show off is when tourists want to be more respected by others, want to show themselves feel more important, want to increase popularity, want to be respected by others, show success, show unique experiences, show to have consumed more trend destination and generally want to show who they are (Serracantallops et al., 2018; Ji \& Yaou, 2017).

Thus the conspicuous tendencies of tourists will be able to strengthen the perceived value relationship with e-WOM activities if tourists want to be more respected by others, want to feel more important, increase popularity, want respect for others, show success in life, show unique experiences, show trends and tourists want to show themselves as adventurers. This notion is reinforced by the assumption that e-WOM tourist activities derived from feelings of happiness, in which happiness will be stronger if tourists who have visited a tourism destination can show their tourist experiences to others, their social status is recognized by others and the experience gained is appreciated by others. These conditions may be difficult for tourism if access to share experiences is not supported by internet-based technology. This condition is supported by studies on conspicuous consumption related to the effect of conspicuous tendencies on tourists' e-WOM activities that are relevant such as: Marder et al., (2018), Amatulli et al., (2018), Kim (2017), Kim et al., (2015).

The moderating role of showing off tendencies is based on previous research by Amatulli et al., (2018) and the logic of thinking that e-WOM tourist behavior, one of which can be strengthened or weakened by the desire to show off of the consumers when tourists obtain the desired value in 
The effect of perceived value by the tourists toward electronic word of mouth activity: the moderating role of conspicuous tendency

the consumption of tourist destinations. Thus the hypotheses proposed are as follows:

H3: Conspicuous tendencies of tourists can be a moderating variable of emotional value effect towards the tourists EWOM activity.

H4: Conspicuous tendencies of tourists can be a moderating variable of epistemic value effect towards the tourists EWOM activity.

\section{Methods}

The approach used in this study is a quantitative approach. The quantitative approach is used since with this approach, the research process is carried out in a structured manner and uses a relatively sufficient number of research samples, which are considered to represent the population under the study. Since the sample used is considered to be representative of the population under the study, the results obtained in this study are conclusive results for the population from which the study sample was taken.

Research requires measuring tools which are able to measure what needs to be measured accurately, so it needs to be arranged as well as possible. Research measuring instruments in the study used criteria of validity and reliability. In measuring variables, the measured variables are stated in indicators. These indicators are the basis for preparing statement items. Measurements were made by using a seven-point differential semantic scale, namely the scale range of numbers 1 for strongly disagree up to number 7 for strongly agree.

The tourist destinations used as objects in this study are tourist destinations which are included in the special interest tourism category which is currently popular, namely adventure tourism. The population in this study is tourists who have conducted tourism activities at adventure tourism destinations, while the study sample was determined by the non probability sampling method. In this sampling technique, the samples taken are those who did the visit in the past three months with the assumption that within this time the visitors still have the ability to remember better. The sample size is set at 400 as a consideration used in the use of Structural Equation Modeling (SEM) models with maximum likelihood (MLE) to get good goodness of fit.

Based on structural equation modeling analysis techniques, research variables can be classified into dependent variables (endogenous variables), independent variables (exogenous variables), latent variables and observed variables (Hair et al., 2014: 549). This study consisted of 4 (four) variables which could not be measured directly, so that indicators were used as gauges for each variable. By using Structural Equation Modeling (SEM) analysis, the seven research variables are called latent variables, while the indicators used as gauges of the seven research variables are called observable variables.

The research variables consist of: 1) Independent variables or exogenous, they are; Emotional value variable which is then called as EMOV, Epistemic value variable which is then called as EPIV and Conspicuous tendencies, which is then called as CT variable. 2) Dependent variables or endogenous is the electronic word of mouth activity which is then called as EWOM variable.

Operational definition and measurement variables are explained as follows:

1. Emotional value variable

Emotional value is a benefit derived from feelings or affections (ie pleasure) produced by a product (Sweeney \& Soutar, 2001). Whereas Sheth et al., (1991) defines emotional value as the ability of products to evoke feelings or affective states of consumers. Emotional value variables in this study are defined as visitor evaluations of perceived benefits in the form of pleasure from the experience of visits that have been carried out. The emotional value variable is measured by indicators adapted from research by Williams et al., (2017) and Williams \& Soutar, (2009). Measurement of these variables is done by using the following indicators: Complacence, Pleasure, Happiness, and Preoccupation

2. Epistemic value variable

The epistemic value is expressed by Ella (2016), as an aspect of surprise or the novelty of a 
product and the capacity of a product to arouse curiosity, provide uniqueness and originality (novelty) or satisfy the desire for knowledge. Another definition is stated by Sheth et al., (1991) that the value of novelty is the consumption of products that lead to curiosity, provide new things and or satisfy the desires of knowledge. The epistemic value variable in the study is the visitor's evaluation of the benefits or novelty value obtained from the overall experience of the tourist destination. The epistemic value variable is measured by indicators adapted from the research of Prebensen \& Xie (2017) and Williams et al., (2017). Measurement of variables is done with the following indicators: Authentic experience, Curiosity satisfaction, Adventurous feeling, Unique experience and New experience

3. Conspicuous tendencies variable

Chaudhuri et al., (2011) states that conspicuous consumption is a deliberate act in symbolic purchases with motivation to communicate a distinctive self-image to others. Jensen \& Gilly, (2003) stated that conspicuous tendencies as a form of excessive self-presentation of the consumption of tourist destinations through social networking sites or blogs. The conspicuous tendencies variable in the study is defined as operational evaluation of the deliberate actions in symbolic purchases with the motivation to communicate or show visiting activities that have been carried out to others (showing off to others), this variable is measured by indicators adapted from Bronner \& de Hoog, (2018) and Phillips \& Back (2011) as follows: Gaining recognition from others, Willing to be more important, Elevating popularity, Demanding respect from others, Showing life achievement, Showing unique experience, Being considered as the early adopter, and Showing oneself off

4. EWOM (Electronic Word of Mouth)

EWOM is all informal communication directed at consumers through internet-based technology related to the use or characteristics of certain goods and services, or the seller (Litvin et al., 2008). Parra-Lopez et al., (2011) defines electronic word of mouth as a recommendation to others through electronic media which provide benefits for sharing photos, videos to personal blogs, rating, evaluating, viewing maps online and so on. The EWOM variable in this study is a positive assessment of visitors on the activity of sharing information, messages, and pictures to other parties through social media. The measurement of the EWOM variable was adapted from the study of Wen et al., (2017), Indicators for measuring variables are as follows: Leaving positive comments about the tourism destination, Posting positive review about the tourism destination, Uploading photos or videos on the social networks, Giving positive recommendation about the tourism destination, Being active in the social media discussing the tourism destination, and Encouraging others to visit the tourism destination online

The analysis technique used in this study is structural equation modeling using the WarpPLS software program. Structural equation modeling is a multivariate analysis technique that is able to analyze a series of multiple dependency relationships between latent variables simultaneously so that it is statistically more efficient (Hair et al, 2014:547).

Measurement models describe the direct relationship between latent variables with observed variables that measure these latent variables. Measurement of all latent variables displayed in the model is evaluated by using the First Order Confirmatory Factor Analysis (CFA). In this study the measurement model will see the loading factor value of the indicator to the latent variable.

The structural model in this study illustrates the causal relationship between latent variables arranged according to theory. The strength of the causal relationship between variables refers to theoretical justification. The basic principle which guides the development of structural models is the parsimony principle, meaning simple models with concise theoretical models (Hair et al, 2014: 545). In the structural model proposed in this study, there is a conspicuous tendencies variable as a moderating variable between emotional value and epistemic value towards the electronic word of mouth (EWOM) activities. 
The effect of perceived value by the tourists toward electronic word of mouth activity: the moderating role of conspicuous tendency

\section{Results and Discussion}

After distributing questionnaire to respondents (adventure tourism's visitors), as many as 400 of respondent filled out the questionnaire completely. Therefore, those 400 data can be used in this study. Based on the data obtained, the identity of the respondent in this study can be categorized in two groups that are gender and education in which it was got 253 respondent were female and 147 were male. For education level, 112 respondents were university students, meanwhile 288 respondents were senior high school students.

The measurement accuracy scale test or validity data test were done to all items of question experienced by tourists consist of emotional value notated as EMOV, epistemic value notated as EPIV, conspicuous tendencies notated as CT and Electronic word of mouth activity notated as EWOM. The measurement accuracy scale test done through validity test and reliability test which explained as follows:

The result of validity test showed in output combined loading and cross-loading, explained in the table as follows:

Table 1: Validity Test

\begin{tabular}{lrrrrrrrrr}
\hline & EMOV & EPIV & EWOM & \multicolumn{1}{c}{ CT } & $\begin{array}{c}\text { CT* } \\
\text { EMOV }\end{array}$ & $\begin{array}{l}\text { CT* } \\
\text { EPIV }\end{array}$ & Type (a) & SE & P value \\
\hline EMOV1 & 0.828 & -0.067 & 0.092 & -0.025 & 0.024 & -0.029 & Reflect & 0.045 & $<0.001$ \\
EMOV2 & 0.885 & -0.067 & 0.013 & -0.017 & -0.037 & 0.025 & Reflect & 0.044 & $<0.001$ \\
EMOV3 & 0.866 & 0.087 & -0.015 & -0.055 & -0.040 & 0.075 & Reflect & 0.044 & $<0.001$ \\
EMOV4 & 0.807 & 0.050 & -0.092 & 0.103 & 0.060 & -0.078 & Reflect & 0.045 & $<0.001$ \\
EPIV1 & 0.137 & 0.807 & -0.109 & 0.033 & 0.080 & -0.060 & Reflect & 0.045 & $<0.001$ \\
EPIV2 & 0.015 & 0.805 & 0.067 & -0.159 & 0.094 & 0.047 & Reflect & 0.045 & $<0.001$ \\
EPIV3 & -0.172 & 0.799 & 0.036 & 0.125 & -0.134 & 0.050 & Reflect & 0.045 & $<0.001$ \\
EPIV4 & -0.079 & 0.835 & -0.050 & 0.061 & -0.051 & -0.010 & Reflect & 0.045 & $<0.001$ \\
EPIV5 & 0.099 & 0.817 & 0.057 & -0.060 & 0.011 & -0.025 & Reflect & 0.045 & $<0.001$ \\
EWOM1 & 0.112 & -0.070 & 0.735 & 0.051 & -0.013 & -0.048 & Reflect & 0.045 & $<0.001$ \\
EWOM2 & 0.077 & -0.121 & 0.812 & 0.057 & 0.072 & -0.052 & Reflect & 0.045 & $<0.001$ \\
EWOM3 & 0.013 & 0.055 & 0.741 & -0.202 & -0.029 & 0.147 & Reflect & 0.045 & $<0.001$ \\
EWOM4 & -0.028 & 0.086 & 0.859 & -0.093 & -0.010 & 0.003 & Reflect & 0.044 & $<0.001$ \\
EWOM5 & -0.043 & -0.046 & 0.831 & 0.205 & -0.026 & -0.026 & Reflect & 0.045 & $<0.001$ \\
EWOM6 & -0.123 & 0.095 & 0.779 & -0.032 & 0.005 & -0.016 & Reflect & 0.045 & $<0.001$ \\
CT1 & 0.101 & 0.035 & -0.177 & 0.839 & 0.012 & -0.034 & Reflect & 0.045 & $<0.001$ \\
CT2 & -0.037 & 0.133 & -0.128 & 0.865 & -0.051 & 0.059 & Reflect & 0.044 & $<0.001$ \\
CT3 & -0.005 & 0.026 & -0.062 & 0.895 & 0.015 & 0.012 & Reflect & 0.044 & $<0.001$ \\
CT4 & 0.006 & -0.012 & -0.121 & 0.902 & 0.042 & -0.019 & Reflect & 0.044 & $<0.001$ \\
CT5 & -0.008 & -0.018 & 0.002 & 0.873 & -0.001 & 0.007 & Reflect & 0.044 & $<0.001$ \\
CT6 & -0.043 & 0.018 & 0.077 & 0.813 & -0.023 & 0.028 & Reflect & 0.045 & $<0.001$ \\
CT7 & -0.058 & -0.086 & 0.299 & 0.808 & -0.018 & 0.007 & Reflect & 0.045 & $<0.001$ \\
CT8 & 0.040 & -0.098 & 0.137 & 0.868 & 0.020 & -0.058 & Reflect & 0.044 & $<0.001$ \\
\hline
\end{tabular}

The first step result of validity test was known that all of indicators had value above 0.5 so that all the items of question or indicators which used to measure latent variable were able to measure variable that will be measured. It can be said that the indicators fulfilled the convergent validity as indicators. Likely the result of the comparison between loading and cross loading, the discriminant va- 
lidity also met the expectation. This result was in line with the statement of Hair et al (2014:123). The accuracy of measurement scale is a must to be fulfilled so further test can be follow up. The scale accuracy showed that each formulated indicator had same basic factor that the items of questions were able to measure the measured construct with the item value had correlation above 0.05.

The value of reliability test was obtained, the coefficient composite reliability value of emotional value (EMOV) was 0.910, conspicuous tendencies value was 0,957 and EWOM was 0.911. Those values were above 0.7 as the requirement of the acceptance of reliability composite test. Meanwhile, the value of internal reliability consistency using Cronbach's alpha coefficient criterion were above 0.60 . Therefore, the reliability of the measurement accuracy scale of all factors of questionnaire had met internal reliability consistency. This statement was accordance with Gliem and Gliem, (2003); Maholtra (1996). All of the result presented in the table as follows:

Table 2: Reliability Test

\begin{tabular}{|c|c|c|c|c|c|}
\hline \multicolumn{6}{|c|}{ R-squared coefficients } \\
\hline \multirow[t]{2}{*}{ EMOV } & EPIV & EWOM & CT & CT*EMOV & CT*EPIV \\
\hline & & 0.232 & & & \\
\hline \multicolumn{6}{|c|}{ Adjusted R-squared coefficients } \\
\hline \multirow[t]{2}{*}{ EMOV } & EPIV & EWOM & CT & CT*EMOV & CT*EPIV \\
\hline & & 0.224 & & & \\
\hline \multicolumn{6}{|c|}{ Composite reliability coefficients } \\
\hline EMOV & EPIV & EWOM & CT & CT*EMOV & CT*EPIV \\
\hline 0.910 & 0.907 & 0.911 & 0.957 & 0.975 & 0.975 \\
\hline \multicolumn{6}{|c|}{ Cronbach's alpha coefficients } \\
\hline EMOV & EPIV & EWOM & CT & CT*EMOV & CT*EPIV \\
\hline 0.868 & 0.871 & 0.882 & 0.949 & 0.973 & 0.974 \\
\hline \multicolumn{6}{|c|}{ Average variances extracted } \\
\hline EMOV & EPIV & EWOM & CT & CT*EMOV & CT*EPIV \\
\hline 0.718 & 0.661 & 0.631 & 0.737 & 0.548 & 0.494 \\
\hline
\end{tabular}

Model Fit Index Test, The result of fit model test used in this study presented in the table, as seen in Table 3.

Table 3: Model Fit and Quality Indices

\begin{tabular}{cllcl}
\hline No & Model fit and Quality Indices & Fit of Criteria & $\begin{array}{c}\text { Analysis of } \\
\text { Results }\end{array}$ & Remarks \\
\hline 1 & Average path coefficient (APC) & $\mathrm{p}<0.05$ & $\mathrm{P}<0.001$ & Good \\
\hline 2 & Average R-squared (ARS) & $\mathrm{p}<0.05$ & $\mathrm{P}<0.001$ & Good \\
\hline 3 & Average adjusted R-squared (AARS) & $\mathrm{p}<0.05$ & $\mathrm{P}<0.001$ & Good \\
\hline 4 & Average block VIF (AVIF) & Acceptable if $<=5$, Ideally $<=3.3$ & 1.862 & Ideal \\
\hline 5 & Average full collinearity VIF (AFVIF) & Acceptable if $<=5$, Ideally $<=3.3$ & 2.211 & Ideal \\
\hline 6 & Tenenhaus GoF (GoF) & $\begin{array}{l}\text { Small }>=0.1, \text { Medium }>=0.25, \\
\text { Large }>=0.36\end{array}$ & 0.383 & Ideal \\
\hline 7 & Sympson's paradox ratio (SPR) & Acceptable if $>=0.7$, Ideally $=1$ & 0.750 & Accepted \\
\hline 8 & R-squared contribution ratio (RSCR) & Acceptable If $>=0.9$, Ideally $=1$ & 0.896 & Low \\
\hline 9 & Statistical suppression ratio (SSR) & Acceptable if $>=0.7$ & 1.000 & Ideal \\
\hline 10 & $\begin{array}{l}\text { Nonlinear bivariate causality direction } \\
\text { ratio (NLBCDR) }\end{array}$ & Acceptable if $>=0.7$ & 0.625 & Low \\
\hline
\end{tabular}


In the fit model test with 10 indexes test that used in order to find out index and fit of the correlation of latent variable and their assumptions, all indicators met the rule of thumb of all good and ideal criteria in the indexes. Therefore, it can be concluded that correlation variable between latent variable was fit.

Model Estimated Test and Path Analysis Test, the analysis was used to find out the effect of emotional value, epistemic value, conspicuous tendencies and electronic word of mouth activity (EWOM) variable. The data obtained were analyzed using warpPLS 5.0. In this study, the test showed that there was direct estimated effect. The result of total effect test presented in this figure 1:

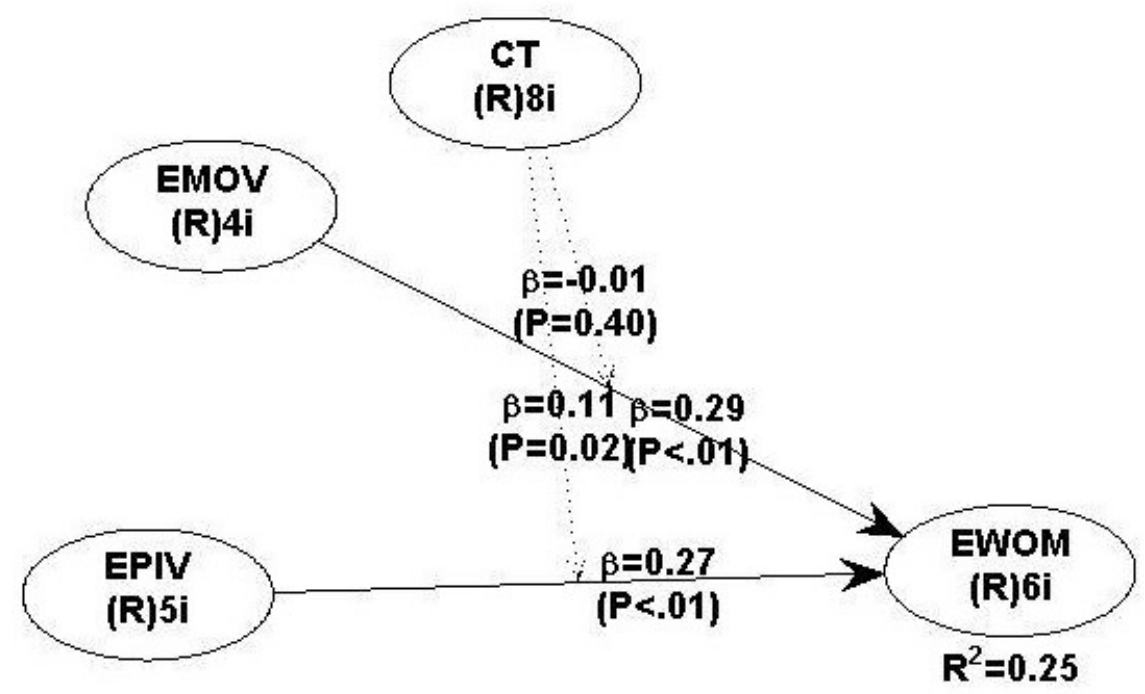

Figure 1: Estimated Value Test

Note: EMOV: emotional value, EPIV: Epistemic value, CT: Conspicuous Tendencies, and EWOM: electronic word of mouth

Based on the analysis result above, it can be arranged model equation of electronic word of mouth activities $=0.27 \mathrm{EMOV}+0.29 \mathrm{EPIV}-0.01 \mathrm{CT} * \mathrm{EMOV}+0.11 \mathrm{CT} * \mathrm{EPIV}$

1. The coefficient of emotional value was 0.27 and coefficient of epistemic value was 0.29 , it had positive value to the electronic work of mouth activity (EWOM), therefore, if emotional value and epistemic value of tourists is higher, it means that it has strong and positive effect to the activity of electronic word of mouth (EWOM) variable.

2. The coefficient of moderation value variable of conspicuous variable of the effect of emotional variable to the activity of electronic word of mouth variable was -0.01 . The moderating variable was negative, it explains that conspicuous tendencies variable weaken the effect of emotional value to the activity of electronic word of mouth (EWOM). Meanwhile, the moderating value variable of conspicuous tendencies to the effect of epistemic value to activity of electronic word of mouth (EWOM) variable was 0.11 , the moderating variable was positive, it explains that conspicuous tendencies variable strengthen the effect of emotional value to the activity of electronic word of mouth (EWOM) variable.

The hypothesis testing, it was used multivariate analysis with Structural Equation Modeling (SEM) using WarpPLS program. Hypothesis test was done by comparing the significant probability value $(p / \alpha)$ set in the value of 0,05 . If $p$-value is greater that probability value, it means that the hypothesis is rejected, if $p$-value is significant and smaller than $\alpha$, it means the hypothesis is accepted. 
Jurnal Siasat Bisnis Vol. 24 No. 1, 2020, 1-17

Table 3: The result of PLS data Analysis

\begin{tabular}{|c|c|c|c|c|c|c|}
\hline \multicolumn{7}{|c|}{ Path coefficients } \\
\hline & EMOV & EPIV & EWOM & CT & CT*EMOV & CT*EPIV \\
\hline \multicolumn{7}{|l|}{ EMOV } \\
\hline \multicolumn{7}{|l|}{ EPIV } \\
\hline EWOM & 0.284 & 0.256 & & & -0.01 & 0.123 \\
\hline \multicolumn{7}{|l|}{$\mathrm{CT}$} \\
\hline \multicolumn{7}{|c|}{ CT*EMOV } \\
\hline \multicolumn{7}{|l|}{ CT*EPIV } \\
\hline \multicolumn{7}{|l|}{$P$ values } \\
\hline & EMOV & EPIV & EWOM & $\mathrm{CT}$ & CT*EMOV & CT*EPIV \\
\hline \multicolumn{7}{|l|}{ EMOV } \\
\hline \multicolumn{7}{|l|}{ EPIV } \\
\hline EWOM & $<0.001$ & $<0.001$ & & & 0.42 & 0.006 \\
\hline \multicolumn{7}{|l|}{ CT } \\
\hline \multicolumn{7}{|c|}{ CT*EMOV } \\
\hline CT*EPIV & & & & & & \\
\hline
\end{tabular}

Table 4: Hypothesis Test

\begin{tabular}{|c|c|c|c|c|c|}
\hline No & Hypothesis & Item & $\begin{array}{l}\beta / \text { Path Coef- } \\
\text { ficient }\end{array}$ & $\begin{array}{c}\mathrm{P}- \\
\text { Value }\end{array}$ & Remarks \\
\hline 1 & $\mathrm{H}_{1}$ & $\begin{array}{l}\text { Emotional Value (EMOV) } \rightarrow \text { Electronic Word } \\
\text { Of Mouth (EWOM) }\end{array}$ & 0.284 & $<0.001$ & $\begin{array}{l}\text { Supported Hy- } \\
\text { pothesis }\end{array}$ \\
\hline 2 & $\mathrm{H}_{2}$ & $\begin{array}{l}\text { Epistemic Value (EPIV) } \rightarrow \text { Electronic Word } \\
\text { Of Mouth (EWOM) }\end{array}$ & 0.256 & $<0.001$ & $\begin{array}{l}\text { Supported Hy- } \\
\text { pothesis }\end{array}$ \\
\hline 3 & $\mathrm{H}_{3}$ & $\begin{array}{l}\text { Emotional Value } \quad(\text { EMOV }) \rightarrow \text { Conspicuous } \\
\text { Tendencies } \quad(\mathrm{CT}) \rightarrow \text { Electronic Word Of } \\
\text { Mouth }(\text { EWOM) }\end{array}$ & -0.01 & 0.42 & $\begin{array}{l}\text { Not Supported } \\
\text { Hypothesis }\end{array}$ \\
\hline 4 & $\mathrm{H}_{4}$ & $\begin{array}{l}\text { Epistemic } \quad \text { Value } \quad(\text { EPIV }) \rightarrow \text { Conspicuous } \\
\text { Tendencies } \quad(\mathrm{CT}) \rightarrow \text { Electronic Word Of } \\
\text { Mouth }(\text { EWOM })\end{array}$ & 0.123 & 0.006 & $\begin{array}{l}\text { Supported Hy- } \\
\text { pothesis }\end{array}$ \\
\hline
\end{tabular}

The result is summarized in table 4 , The hypothesis test presented in the table can be explained as follows:

1. Emotional value variable affected electronic word of mouth (EWOM). The result showed that direct coefficient effect of emotional value to electronic word of mouth (EWOM) activity was 0.284. It means that emotional value variable had positive correlation to the activity of electronic word of mouth (EWOM) variable. The significant value of emotional value was 0,001<0,05. It showed that $\mathrm{H} 1$ was accepted. Therefore, it can be said that emotional value affected the electronic word of mouth (EWOM) activity

2. Epistemic value variable gave effect to electronic word of mouth (EWOM) activity. The result of hypothesis test showed that direct coefficient effect of epistemic to electronic word of mouth (EWOM) activity was 0.256 . It means that epistemic value variable had positive correlation to the activity of electronic word of mouth (EWOM) variable. The significant value of epistemic value variable was $0,001<0,05$. It showed that $\mathrm{H} 2$ was accepted. Therefore, it can be concluded that epistemic value affected the electronic word of mouth (EWOM) activity.

3. Conspicuous tendencies variable of the tourists became the moderating variable of the effect of emotional value to electronic word of mouth (EWOM) activity. The result showed that conspic- 
The effect of perceived value by the tourists toward electronic word of mouth activity: the moderating role of conspicuous tendency

uous tendencies variable as moderating variable had value of $-0,01$ with $p$-value was 0.42 . The value of coefficient moderation was negative and $p$ value was greater that $p$-value of 0.05 . It showed that $\mathrm{H} 3$ was rejected. Therefore, it can be said that conspicuous tendencies variable were not able to became moderating effect of emotional variable value to the electronic word of mouth (EWOM) activity.

4. Conspicuous tendencies variable of the tourists can become moderating effect variable of emotional value to electronic word of mouth (EWOM) activity. The result showed that conspicuous tendencies variable as the moderator variable had value of 0.123 with $p$-value was smaller than $\mathrm{p}$-value of 0.05 . It showed that $\mathrm{H} 4$ was accepted. It means that conspicuous tendencies variable were able to become moderating effect of emotional variable to electronic word of mouth (EWOM) activity.

After the result obtained, discussion of each result based on the test can be done. Emotional value variable affected the activity of electronic word of mouth. The result showed that the direct coefficient effect of emotional value to electronic word of mouth activity was 0.284 . It means that emotional value variable had positive effect to electronic word of mouth (EWOM) activity variable. This result gave information that the higher emotional value such as complacence, pleasure, happiness, and pre occupation felt by the tourist, the higher activity of electronic word of mouth (EWOM) will be by sharing adventurous tour experience through social media. This result was supported by the significant value of emotional value variable in the value of $0,001<0,05$. It showed that there was an effect of emotional value to the activity of electronic word of mouth (EWOM). This study supports some studies done by Bora et al., (2018); Mukerjee, (2018); Young et al., (2018); Kim et al., (2018); Antón et al., (2017); Ranaweera \& Karjaluoto, (2017); Varshneya et al., (2017). Emotional value had dominant effect to epistemic value variable as explained by Williams et al., (2017) that emotional value and epistemic value became strong predictor of the satisfaction of tourists. Therefore, in this study, emotional value and epistemic value became important part of tourists' experience value.

Epistemic value variable affected the activity of electronic word of mouth. The result of test showed that the coefficient direct impact of epistemic value to electronic word mouth activity was 0.256. It means that epistemic value had positive effect to the activity of electronic word of mouth value. This result gave information that the higher epistemic value perceived by the tourist such as authentic experience, curiosity satisfaction, adventurous feeling, unique experience, and new experience, the higher of EWOM activity will be done by tourist in every adventurous tour experience by sharing on social media. This result was supported by the significant value of epistemic variable in the value of $0,001<0,05$. This showed that there was an effect of epistemic value to the activity of electronic word of mouth. This study supports studies done by Bora et al., (2018); Kim et al., (2018) Mukerjee, (2018); Young et al., (2018); Antón et al., (2017); Ranaweera \& Karjaluoto, (2017).

Conspicuous tendencies variable of tourist were not able to become moderating variable for the effect of emotional value to electronic word of mouth activity of the tourist. The result of moderator effect showed that conspicuous tendencies variable had value of $-0,01$ with $p$ in the value of 0.42. The value of moderation coefficient was negative and $p$-value was higher than $p$ value of 0.05 . It means the existence of conspicuous tendencies will weaken the effect of emotional value variable to the activity of electronic word of mouth of the tourist. Therefore, it can be said that conspicuous tendencies variable cannot become moderating variable of the effect of emotional value to the electronic word of mouth activity. For example, writing positive comment about the tourism destination, posting positive review about the tourism destination, uploading photos or videos on social media, giving positive recommendation about the tourism destination, being active on social media group which review the tourist attraction, encouraging people to visit the tourism destination online. However, this result was not in line with study done by Chaudhuri et al., (2011); Wang \& Liu, (2007).

Conspicuous tendencies variable were able to become moderating variable for the effect of 
emotional value to electronic word of mouth activity of the tourist. The result of the test showed that conspicuous tendencies as the moderating variable had the value of 0.123 with $p$-value of 0.006. The value of coefficient moderation was positive and $p$-value was smaller than $p$ value of 0.05. It showed that the existence of conspicuous tendencies were able to become moderator which can strengthen the effect of epistemic value to electronic word of mouth of tourist. Therefore, it can be said that conspicuous tendencies were able to become strong moderation in the effect of epistemic value to the electronic world of mouth activity. For example writing positive comment about the tourism destination, posting positive review about the tourism destination, uploading photos or videos on social media, giving positive recommendation about the tourism destination, being active on social media group which review the tourism destination, encouraging people to visit the tourism destination online. This result was in line with the previous studies done by Chaudhuri et al., (2011); Wang \& Liu, (2007). This study also gave information that if the need of conspicuous was high such as gaining recognition from others, willing to be more important, raising popularity, demanding respect, showing life achievement, showing unique experience that cannot be owned by others, demanding to be recognized as the early adopter and showing oneself off, it will make the tourists got authentic experience that could satisfy their curiosity, adventurous feeling, unique experience, and new experience.

\section{Conclusion}

Based on the set of research process, data process, and data analysis, the researcher can draw conclusion based on the objectives of the study. It can be concluded that emotional value affected the activity of electronic word of mouth (EWOM) of the tourist, epistemic value affected electronic word of mouth (EWOM) of the tourist, conspicuous tendencies variable of the tourists weaken the impact of emotional value to the activity of electronic word of mouth (EWOM) of the tourist, and the last, conspicuous tendencies of the tourists strengthen the effect of emotional value to the activity of electronic word of mouth (EWOM) of the tourist. The result of the study can give managerial contribution to the management such as the tourism destination manager should be more concern to the need of the values perceived by the tourists after their visiting. It is because only tourist who got more expected value will write positive comment about the tourism destination, will post positive review about the tourism destination, will upload photos or videos on their social media, give positive recommendation, will active on social media group which review the tourism destination, and encourage other people to visit the tourism destination. The theoretical contribution of the study is a discovery theory that there was a paradox result of the study. The effect of emotional value was higher than epistemic value. However, conspicuous tendencies as the moderating variable weaken the emotional value but strengthen the epistemic value variable so that for further research a value obtained by tourist can be considers as uni-dimensional variable or the usage of the variable can be used in certain artificial tourism destination.

\section{References}

Albaity, M., \& Melhem, S. B. (2017). Novelty seeking, image, and loyalty the mediating role of satisfaction and moderating role of length of stay: International tourists' perspective. Tourism management perspectives, 23, 30-37

Amatulli, C., De Angelis, M., Korschun, D., \& Romani, S. (2018). Consumers' perceptions of luxury brands' CSR initiatives: An investigation of the role of status and conspicuous consumption. Journal of Cleaner Production, 194, 277-287

Antón, C., Camarero, C., \& Laguna-garcía, M. (2017). Experience Value or Satiety ? The Effects of the Amount and Variety of Tourists ' Activities on Perceived Experience. Journal of Travel Research, 1-16. 
The effect of perceived value by the tourists toward electronic word of mouth activity: the moderating role of conspicuous tendency

Bajac, H., Palacios, M., \& Minton, E. A. (2018). Consumer-brand congruence and conspicuousness: an international comparison. International Marketing Review, 35(3), 498-517.

Basri, Faisal, (2017), pergeseran pola konsumsi (online), https://faisalbasri.com/2017/08/14/pergeseran-pola-konsumsi/, Retrieved October 1, 2018

Bora, B. D., Bilgihanb, A., Ye, B. H., Buonincontrid, P., \& Okumus, F. (2018). The impact of servicescape on hedonic value and behavioral intentions: The importance of previous experience. International Journal of Hospitality Management, 72, 10-20.

Bronner, F., \& de Hoog, R. (2018). Conspicuous consumption and the rising importance of experiential purchases. International Journal of Market Research, 60(1), 88-103.

Bronner, F., \& de Hoog, R. (2018). Comparing conspicuous consumption across different experiential products: Culture and leisure. International Journal of Market Research, 1-17

Chaudhuri, H. R. O. Y., Mazumdar, S., \& Ghoshal, A. (2011). Conspicuous consumption orientation: Conceptualisation, scale development and validation. Journal of Consumer Behaviour, 10, 216-224.

Chen, C. F., Leask, A., \& Phou, S. (2016). Symbolic, experiential and functional consumptions of heritage tourism destinations: The case of angkor world heritage site, cambodia. International Journal of Tourism Research, 18(6), 602-611.

Chen, H., \& Rahman, I. (2018). Cultural tourism: An analysis of engagement, cultural contact, memorable tourism experience and destination loyalty. Tourism Management Perspectives, 26 (September 2017), 153-163.

Dev, M., Podoshen, J. S., \& Shahzad, M. (2018). An Exploratory Comparison of Materialism and Conspicuous Consumption in Pakistan. Journal of International Consumer Marketing, 0(0), $1-9$.

Ekinci, Y., Sirakaya-turk, E., \& Preciado, S. (2013b). Symbolic consumption of tourism destination brands. Journal of Business Research, 66(6), 711-718.

Ella, P. M. F. (2016). Pengaruh Self Congruity Terhadap Niat Perilaku Dengan Experiential Value Sebagai Variabel Mediasi (Pada Wisatawan Destinasi Wisata Kota Banda Aceh). Jurnal Ilmiah Mahasiswa Ekonomi Manajemen, 1(1), 37-56.

Esmaeilpour, F. (2015). The role of functional and symbolic brand associations on brand loyalty: A study on luxury brands. Journal of Fashion Marketing and Management, 19(4), 467-484.

Gazley, A., \& Watling, L. (2015). Me, my tourist-self, and I: the symbolic consumption of travel. Journal of Travel \& Tourism Marketing, 32(6), 639-655.

Gbadamosi, A. (2015), Brand Personification and Symbolic Consumption Among Ethnic Minority Teenage Consumers: An Empirical Study. Journal of Brand Management Vol. 22, 9, 737754.

Giddy, J. K. (2018). A profile of commercial adventure tourism participants in South Africa. Anatolia, 29(1), 40-51.

Giddy, J. K., \& Webb, N. L. (2016). The influence of the environment on motivations to participate in adventure tourism: The case of the Tsitsikamma. South African Geographical Journal, 98(2), 351-366.

Giddy, J. K., \& Webb, N. L. (2018). Environmental attitudes and adventure tourism motivations. GeoJournal, 83(2), 275-287.

Gliem, J. A., \& Gliem, R. R. (2003). Calculating, interpreting, and reporting Cronbach's alpha reliability coefficient for Likert-type scales. Midwest Research-to-Practice Conference in Adult, 


\section{Continuing, and Community Education.}

Hair, J. F., Black, W. C., Babin, B. J., \& Anderson, R. E. (2014). Multivariate data analysis: Pearson new international edition. Essex: Pearson Education Limited.

Halim, A. H. A., \& Mokhtar, A. R. M. (2016). Creating memorable visitor experiences by assessing the satisfaction level and behavioural consequences of attendees. Procedia Economics and Finance, 37, 1-6.

Han, S. H., Nguyen, B., \& Simkin, L. (2016). The dynamic models of consumers' symbolic needs: in the context of restaurant brands. European Journal of Marketing, 50(7/8), 1348-1376.

House, M., Hwang, J., \& Hyun, S. S. (2015). Perceived Firm Innovativeness in Cruise Travelers' Experience and Perceived Luxury Value: The Moderating Effect of Advertising Effectiveness Perceived Firm Innovativeness in Cruise Travelers' Experience and Perceived Luxury Value: The Moderating Effec. Asia Pacific Journal of Tourism Research, (March 2015), 37-41.

Jamal, S. A., Aminudin, N., \& Kausar, D. R. (2019). Family adventure tourism motives and decisionmaking: A case of whitewater rafting. Journal of Outdoor Recreation and Tourism, 25, 1015.

Jensen, S. H., \& Gilly, M. C. (2003). We are what we post? Self-presentation in personal web space. Journal of consumer research, 30(3), 385-404.

Kim, D., \& Jang, S. (2017). Symbolic consumption in upscale cafés: Examining Korean gen Y consumers' materialism, conformity, conspicuous tendencies, and functional qualities. Journal of Hospitality \& Tourism Research, 41(2), 154-179.

Kim, D., Jang, S., \& Adler, H. (2015). What drives café customers to spread eWOM? Examining self-relevant value, quality value, and opinion leadership. International Journal of Contemporary Hospitality Management, 27(2), 261-282.

Kim, J. J., Nam, M., \& Kim, I. (2018). The effect of trust on value on travel websites: enhancing well-being and word-of-mouth among the elderly. Journal of Travel \& Tourism Marketing, $1-14$.

Kwak, D. H., \& Kang, J.-H. (2009), Symbolic Purchase In Sport: The Roles Of Self-Image Congruence And Perceived Quality. Management Decision Vol. 47 47(1): 16.

Larsen, G., Lawson, R., \& Todd, S. (2010). The symbolic consumption of music. Journal of Marketing Management, 26(7-8), 671-685

Lee, Y. (2016). Relationship quality and its causal link to service value, satisfaction, and word-ofmouth. Services Marketing Quarterly, 37(3), 171-184.

Lin, C. \& Kuo, B. Z. (2016). The Behavioral Consequences of Tourist Experience. Tourism Management Perspectives, 18, 84-91

Litvin, S. W., Goldsmith, R. E., \& Pan, B. (2008). Electronic Word of Mouth in Hospitality and Tourism Management. Tourism Management, 29, 458-468

Liu, F., Li, J., Mizerski, D., \& Soh, H. (2012). Self-congruity, brand attitude, and brand loyalty: a study on luxury brands. European Journal of Marketing, 46(7/8), 922-937.

Lu, J. \& Xu, Y. (2015). Chinese young consumers' brand loyalty toward sportswear products: a perspective of. Journal of Product \& Brand Management, 24(4), 365-376.

Maholtra, Naresh K. (1996). Marketing Research: An applied Orientation. Second Edition. Prentice Hall International, Inc.

Mukerjee, K. (2018). The impact of brand experience, service quality and perceived value on word 
The effect of perceived value by the tourists toward electronic word of mouth activity: the moderating role of conspicuous tendency

of mouth of retail bank customers: Investigating the mediating effect of loyalty. Journal of Financial Services Marketing, 23(1), 12-24

Nabi, N., O'Cass, A. \& Siahtiri, V. (2019). Status consumption in newly emerging countries: The in $\mathrm{fl}$ uence of personality traits and the mediating role of motivation to consume conspicuously. Journal of Retailing and Consumer Services, 46(April 2017), 173-178.

O'Cass, A. (2018). Exploring consumer status and conspicuous consumption. Journal of Consumer Behaviour, 4(1), 25-39

Oh, H. (1999). Service quality, customer satisfaction, and customer value: A holistic perspective. International Journal of Hospitality Management, 18(1), 67-82

Parra-López, E., Bulchand-Gidumal, J., Gutiérrez-Taño, D., \& Díaz-Armas, R. (2011). Intentions to use social media in organizing and taking vacation trips. Computers in Human Behavior, 27(2), 640-654.

Phillips, W. J., \& Back, K. J. (2011). Conspicuous consumption applied to tourism destination. Journal of Travel \& Tourism Marketing, 28(6), 583-597.

Pomfret, G., \& Bramwell, B. (2016). The characteristics and motivational decisions of outdoor adventure tourists: A review and analysis. Current Issues in Tourism, 19(14), 1447-1478.

Prebensen, N. K., \& Rosengren, S. (2016). Experience value as a function of hedonic and utilitarian dominant services. International Journal of Contemporary Hospitality Management, 28(1), 113-135.

Prebensen, N. K., Woo, E., \& Uysal, M. S. (2014). Experience value: Antecedents and consequences. Current Issues in Tourism, 17(10), 910-928.

Ranaweera, C., \& Karjaluoto, H. (2017). The impact of service bundles on the mechanism through which functional value and price value affect WOM intent. Journal of Service Management, 28(4), 707-723.

Sangpikul, Aswin. (2017). Article information: The effects of travel experience dimensions on tourist satisfaction and destination loyalty: the case of an island destination. International Journal of Culture, Tourism and Hospitality Research, 1-15.

Serra-Cantallops, A., Ramon-Cardona, J., \& Salvi, F. (2018). The impact of positive emotional experiences on eWOM generation and loyalty. Spanish Journal of Marketing-ESIC.

Shao, W., Grace, D., \& Ross, M. (2019). Motivation and luxury consumption: Testing moderating effects. Journal of Retailing and Consumer Services, 46(April 2018), 33-44

Sheth, J. N., Newman, B. I., \& Gross, B. L. (1991). Why we buy what we buy: A theory of consumption values. Journal of Business Research, 22(2), 159-170.

Sun, X., Wang, P., Lepp, A., \& Robertson, L. (2014). Symbolic consumption and brand choice: China's youth hostels for the international travel market. Journal of China Tourism Research, 10(1), 51-68.

Sweeney, J. C. \& Soutar, G. N. (2001). Consumer perceived value: The development of a multiple item scale. Journal of Retailing, 77(2), 203-220

Varshneya, G., Das, G., \& Khare, A. (2017). Experiential value: a review and future research directions. Marketing Intelligence \& Planning, 35(3), 339-357.

Wang, X., \& Liu, J. (2007). The Relationship between Perceived Performance and Consumer Satisfaction: The Moderating Role of Price, Price Consciousness and Conspicuous Consumption. In IEEE (Ed.), 2007 International Conference on Service Systems and Service Management (pp. 0-5). Chengdu, China. 
Wen, J., Hu, Y., \& Kim, H. J. (2017). Impact of individual cultural values on hotel guests' positive emotions and positive eWOM intention: Extending the cognitive appraisal framework. International Journal of Contemporary Hospitality Management, 30(3), 1769-1787.

Williams, P., \& Soutar, G. N. (2009). Value, satisfaction and behavioral intentions in an adventure tourism context. Annals of Tourism Research, 36(3), 413-438.

Williams, P., Soutar, G., Jeremy, N., Earl, A., Williams, P., Ashill, N. J., \& Naumann, E. (2017). Value drivers and adventure tourism Western consumers. Journal of Service Theory and Practice, 27(1), 102-122

Wymer Jr, W. W., \& Samu, S. (2002). Volunteer service as symbolic consumption: Gender and occupational differences in volunteering. Journal of Marketing Management, 18(9-10), 971989.

Xu, J. B., \& Chan, S. (2016). A new nature-based tourism motivation model: Testing the moderating effects of the push motivation. Tourism Management Perspectives, 18, 107-110.

Young, J., Choe, J., \& Sam, S. (2018). Effects of tourists' local food consumption value on attitude, food destination image, and behavioral intention. International Journal of Hospitality Management, 71(May 2017), 1-10. 